\title{
Penerapan Dashboard Sebagai Media Pengumpulan Data Laporan Penulisan Mahasiswa di Widuri Menggunakan Rinfo Spreadsheet Pada Perguruan Tinggi
}

\author{
Indri Handayani $^{1}$ \\ Dian Kurniati ${ }^{2}$ \\ Saeful Aenul Yakin ${ }^{3}$ \\ Dosen STMIK Raharja ${ }^{1}$, Mahasiswi STMIK Raharja jurusan Sistem Informasi ${ }^{2,3}$ \\ E-mail: indri@raharja.info ${ }^{\prime}$; dian.kurniati@raharja.info ${ }^{2}$; aenulyakin@raharja.info ${ }^{3}$
}

\begin{abstract}
ABSTRAK
Dashboard adalah satu aplikasi yang secara real time akan memonitoring berbagai informasi yang dibutuhkan oleh suatu organisasi atau perusahaan dengan berbagai macam format. Dengan adanya perkembangan teknologi informasi yang canggih, saat ini Widuri yang merupakan salah satu website yang ada di Perguruan Tinggi Raharja ternyata belum menerapkan dashboard pada website tersebut sehing ga menyulitkan para admin widuri dalam merekap laporan performa widuri wayang. Maka diperlukannya penerapan dashboard pelaporan penulisan Widuri pada Website Widuri dengan menggunakan mediawiki yang bisa menampung dan mengolah data untuk dijadikan sebuah informasi yang dibutuhkan.
\end{abstract}

Kata kunci : Dashboard, Widuri, Informasi

\begin{abstract}
Dashboard is an application that in real time will monitor various information needed by an organization or company with various formats. With the development of sophisticated information technology, this time Widuri is one of the websites in the College Raharja was not yet apply the dashboard on the website so difficult for the administrators of widuri in recording performance reports puppet widuri. So the need for the application of dashboard reporting Widuri writing on Widuri Website by using mediawiki that can accommodate and process data to be a needed information.
\end{abstract}

Keywords: Dashboard, Widuri, Information

\section{PENDAHULUAN}

Menurut Dwi Januarita (2015) $)^{[1]}$ Dashboard adalah tampilan visual dari informasi penting yang diperlukan untuk mencapai satu atau beberapa tujuan dengan mengkonsolidasikan dan mengatur informasi dalam satu layar sehingga kinerja organisasi dapat dimonitor secara sekilas.

Dashboard, atau yang biasa lebih dikenal dengan Viewboard pada Perguruan Tinggi Raharja merupakan suatu sistem yang dapat mengumpulkan, mengelola atau menyajikan data dan informasi untuk menampilkan data statistik secara akurat, dimana viewboard itu sendiri berfungsi untuk memberikan suatu informasi yang dibutuhkan atau informasi penting untuk diketahui secara umum. Dalam meningkatnya kebutuhankebutuhan informasi yang real-time yang memacu teknologi informasi untuk 
berkembang lebih pesat sesuai dengan kebutuhan yang dibutuhkan agar pemanfaatan teknologi informasi dapat digunakan untuk memperbaiki kualitas ketentuan penulisan laporan pada Widuri. Perkembangan teknologi informasi tersebut dapat di terapkan dan di manfaatkan ke dalam sistem Dashboard yang ada pada Website Widuri.

Menurut Technology Partners (2014) $)^{[2]}$, Viewboard is a custom application created by Technology Partners, with it you can have the most important information you need to make mission critical business decisions on a daily basis in one easy to read dashboard. From metrics and socials to department level critical information, you decide what you want to have in your custom dashboard. The dashboard interface is fully dynamic, you are able to connect it to a CMS system or have it directly access your database to manage the information feeds. Dari definisi tersebut dapat disimpulkan bahwa viewboard adalah aplikasi custom yang dibuat oleh Mitra Teknologi, yang fungsinya agar dapat mengetahui informasi penting dan juga informasi yang dibutuhkan.

Saat ini proses pengambilan keputusan dalam penggunaan fasilitas yang ada di Perguruan Tinggi Raharja masih menggunakan penginputan Microsoft Excel yang bisa hilang kapan saja dan data tersebut bisa saja tidak tersimpan otomatis, padahal sudah ada website Widuri yang gunanya untuk memberikan kemudahan bagi mahasiswa dalam melihat jumlah laporan yang diterima oleh Widuri.

Informasi yang ada di dalam Dashboard atau Viewboard Widuri dapat digunakan untuk melihat berapa banyak mahasiswa yang telah membuat penulisan laporan pada Widuri. Informasi tersebut tentunya sangat berguna untuk para mahasiswa yang bersangkutan dan admin tidak lagi harus menginput data pada Microsoft Excel sehingga admin tidak lagi sulit dalam merekap data laporan penulisan mahasiswa .

Dalam pembuatan Dashboard Widuri dimana peneliti memanfaatkan sebuah Rinfo Spreadsheet atau yang lebih dikenal sebagai Google Spreadsheet. Google Spreadsheet atau Rinfo Spreadsheet merupakan salah satu tools yang sudah disediakan oleh Google secara gratis, dapat diakses dimana saja dan kapan saja.

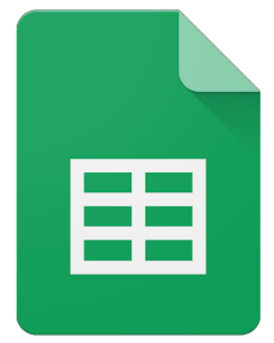

Gambar 1. Logo Google Spreadsheet

Sumber: google.com

\section{PERMASALAHAN}

Dalam proses pembuatan sebuah laporan mengenai data laporan penulisan mahasiswa yang ada pada Widuri memerlukan waktu yang tidak sedikit dan banyaknya menggunakan kertas sehingga memerlukan banyak biaya yang dikeluarkan. Dan juga sulitnya bagi mahasiswa mengetahui secara langsung mengenai laporan yang telah lolos 
pada Widuri dan juga laporan yang tidak lolos pada Widuri. Sehingga sulitnya bagi admin dan mahasiswa dalam mengambil keputusan.

Dari permasalahan yang telah terjadi, perlu adanya sebuah inovasi yang bermanfaat, seperti membuat sebuah dashboard yang dapat menampilkan sebuah informasi agar tidak lagi sulit bagi admin dan mahasiswa dalam mengambil keputusan. Dan juga dapat dengan mudah mengetahui seberapa banyak mahasiswa yang telah membuat laporan penulisan pada Widuri. Dibuatnya pengumpulan data menggunakan Microsoft Excel tidak dapat di share secara online dan hanya dilihat oleh seseorang yang memiliki folder tersebut.

Rumusan masalah pada penelitian ini yaitu bagaimana penerapan pengumpulan data laporan penulisan secara online untuk mahasiswa pada Perguruan Tinggi Raharja dengan menggunakan Rinfo Spreadsheet. Berdasarkan rumusan masalah yang telah diidentifikasi maka tujuan yang ingin dihasilkan adalah penerapan dashboard dalam pengumpulan data laporan penulisan yang dapat diakses secara online dan dapat memudahkan mahasiswa dalam melihat jumlah laporan penulisan pada Widuri.

\section{METODOLOGI PENELITIAN}

Penelitian ini berbetuk studi kasus dengan Metode penelitian berupa : 1. Metode Observasi, 2. Metode Wawancara, 3. Metode Literature Review. Peneliti melakukan Metode Observasi secara langsung pada Perguruan Tinggi Raharja, Metode Wawancara yang dilakukan oleh peneliti dengan cara mewawancarai langsung kepada dosen yang bersangkutan. Metode Literature Review yang dilakukan oleh peneliti dengan cara mencari, membaca dan memahami berbagai sumber referensi yang ada seperti jurnal dan buku.

Berdasarkan ini adalah beberapa Literature Review yang digunakan dalam penelitian ini

1. Penelitian ini dilakukan oleh Antonio Scipioni, Anna Mazzi, Marco Mason, dan Alessandro Manzardo pada tahun 2008 dengan judul "The Dashboard of Sustainability to measure the local urban sustainable development: The case study of Padua Municipality" menjelaskan bahwa dengan mewakili konteks yang diamati dengan cara yang sederhana - dapat membantu masyarakat dalam menentukan tujuan perbaikan yang efektif dan juga berfungsi sebagai alat penting untuk memantau pemenuhan tujuan yang direncanakan. Dashboard of Sustainability (DS) adalah alat matematika dan grafis yang dirancang untuk mengintegrasikan pengaruh keberlanjutan yang kompleks dan mendukung proses pengambilan keputusan dengan menciptakan evaluasi yang ringkas. ${ }^{[3]}$

2. Penelitian ini dilakukan oleh Bruce d. McCullough dan a. Talha Yalta pada tahun 2013 dengan judul "Spreadsheets in the Cloud - Not Ready Yet" menjelaskan bahwa Komputasi awan adalah teknologi yang relatif baru yang memfasilitasi inovasi dan modifikasi dokumen melalui internet secara real time. Disini kami menyediakanpengantar penilaian terhadap fungsi statistik yang tersedia di tiga spreadsheet cloud terkemuka yaitu Google Spreadsheet, Microsoft Excel Web App dan Zoho Sheet. Hasil kami menunjukkan bahwa pengembang spreadsheet berbasis 
Internet tidak melakukan kontrol kualitas dasar, menghasilkan perhitungan statistik yang menyesatkan dan tidak benar. Selain itu, pengembang tidak menyediakan cukup informasi tentang perangkat lunak dan perangkat keras, yang bisa diubah kapan saja tanpa pemberitahuan. Memang, saat menjalankan tes lagi setelah beberapa bulan kita mendapatkan hasil yang berbeda dan terkadang lebih buruk. ${ }^{[4]}$

3. Penelitian yang dilakukan oleh Khanna Tiara, Erlita Rasdiana dan Nursam Somantri yang berjudul "Penerapan RinfoSheet Sebagai Media Penunjang Pembuatan Laporan Untuk Mahasiswa" menjelaskan bahwa dalam penelitian ini peneliti merasa cara pembelajaran (pembuatan laporan) yang sedang berjalan di Perguruan Tinggi masih berjalan dengan manual dan membutuhkan banyak kertas dan membuang banyak waktu. Sehingga proses pembuatan laporan tersebut penulis memilih menggunakan sarana Google Sheet atau yang lebih di kenal di Perguruan Tinggi tersebut sebagai Rinfo Sheet karena pembuatan laporan sudah bisa dikerjakan melalui online dengan menggunakan media Gmail atau Rinfo yang sudah tersedia pada Perguruan Tinggi. Dengan menggunakannya Google Sheet pembuatan laporan dapat memudahkan mahasiswa dalam proses pembuatan laporan mahasiswa di Perguruan Tinggi. ${ }^{[5]}$

4. Penelitian yang dilakukan oleh Ary Budi Warsito, Muhamad Yusup, dan Erlita Rasdiana pada tahun 2014 dengan judul "Pemanfaatan Rinfodocs Sebagai Media Penyusunan Draft Laporan Dalam Proses Bimbingan Tugas Akhir Pada Perguruan Tinggi” menjelaskan bahwa untuk mendukung agar sistem pembelajaran dapat lebih memudahkan mahasiswa maupun dosen pembimbing dengan memanfaatkan RinfoDocs sebagai media untuk mendukung proses bimbingan laporan Tugas Akhir. RinfoDocs merupakan salah satu fitur ada di RinfoDrive yang disediakan oleh Rinfo. Dengan adanya RinfoDocs proses pembelajaran dapat dilakukan secara online karena dapat dilakukan dimanapun dan kapanpun. Melalui pemanfaatan RinfoDocs dapat memudahkan proses penyusunan draft laporan dalam proses bimbingan Tugas Akhir pada perguruan tinggi. ${ }^{[6]}$

5. Penelitian ini dilakukan oleh Indri Handayani, Herrafika Kusumahati, dan Alpiah Nurul Badriah pada tahun 2017 dengan judul "Pemanfaatan Google Spreadsheet Sebagai Media Pembuatan Dashboard pada Official Site iFacility di Perguruan Tinggi" menjelaskan bahwa Dashboard merupakan tampilan yang didalamnya terdapat informasi penting yang digunakan untuk mengambil sebuah keputusan. Diperlukannya penerapan dashboard pelaporan AC pada Official site iFacility dengan menggunakan salah satu fitur google yaitu Google Spreadsheet yang bisa dimanfaatkan untuk menampung data dan mengolah data untuk dijadikan sebuah informasi yang dibutuhkan. ${ }^{[7]}$

\section{HASIL DAN PEMBAHASAN}

\subsection{Analisa Permasalahan}


Perguruan Tinggi Raharja saat ini mempunyai berbagai sistem yang telah dikembangkan untuk memberikan kemudahan dalam memperoleh informasi secara akurat. Salah satu sistem yang saat ini dikembangkan yaitu Website Widuri yang khusus membahas data laporan penulisan mahasiswa Widuri pada Perguruan Tinggi Raharja, namun pemanfaatan sistem tersebut dirasa kurang dimanfaatkan karena belum adanya Dashboard atau Viewboard laporan penulisan mahasiswa Widuri untuk mendapatkan informasi perihal data keseluruhan laporan mana saja yang sudah lolos scan laporan penulisan, laporan penulisan yang plagiat, laporan penulisan yang tidak lengkap dan yang tidak membuat laporan di Widuri.

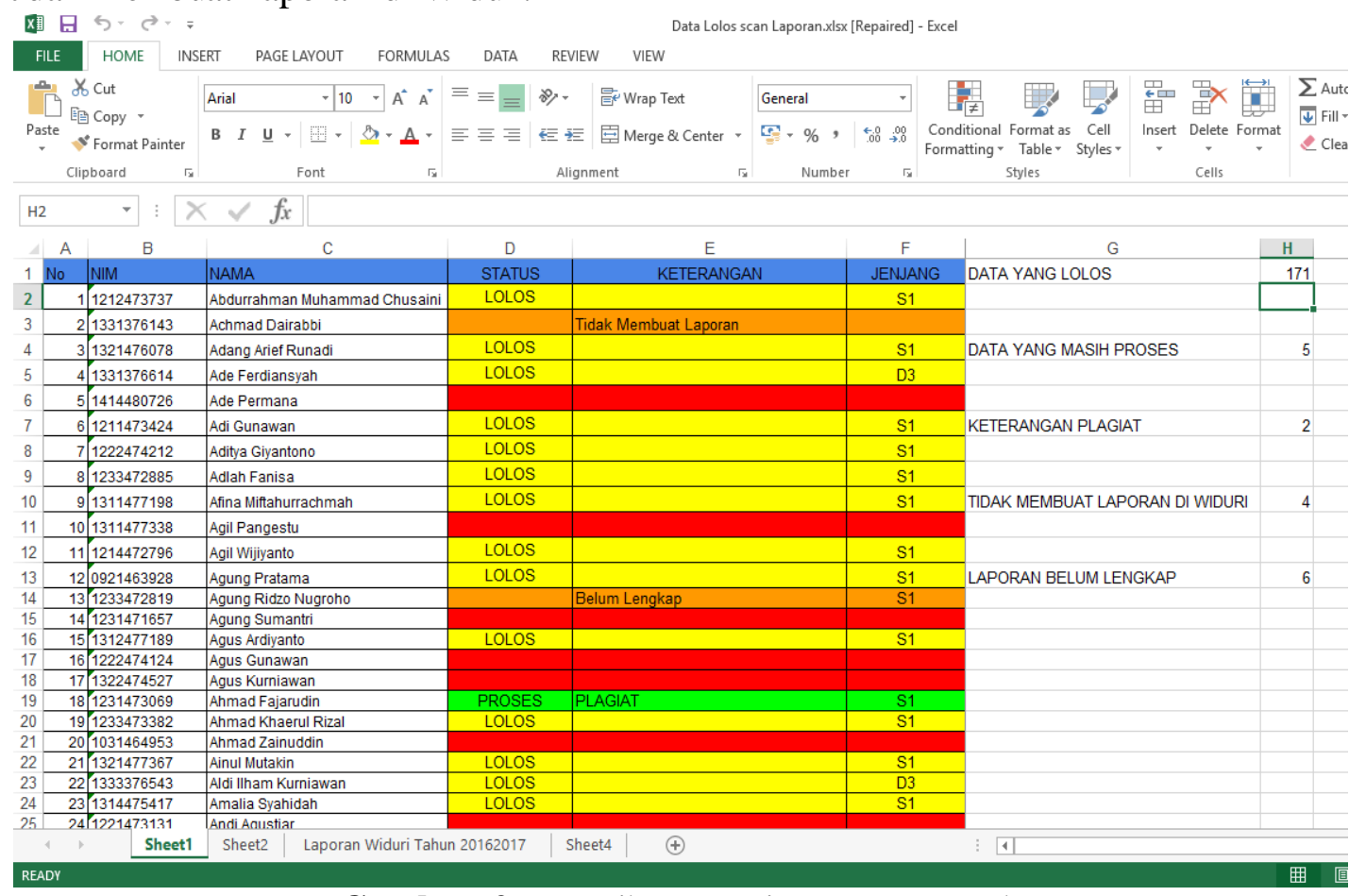

Gambar 2. Tampilan Penginputan Manual

Gambar diatas merupakan tampilan penginputan data laporan penulisan pada Widuri menggunakan Microsoft Excel yang dilakukan secara manual sehingga membutuhkan waktu yang sangat lama dan saat penginputan data bisa saja tidak terinput. Maka hasil dari informasi yang didapat tidak akurat karena data yang didapat bisa saja salah, selain itu jika diinput dalam Microsoft Excel para Tim Widuri tidak semuanya tahu karena hanya admin Widuri yang mengetahui data yang diinput melalui Microsoft Excel yang artinya data tersebut masih offline. Dan dapat disimpulkan dari permasalahan yang sudah dijabarkan maka penerapan dashboard pada Website Widuri dapat diterapkan sehingga mampu mempermudah Tim Widuri dalam mendapatkan informasi terupdate dan juga informasi yang detail serta mendapatkan informasi yang akurat untuk suatu pengambilan keputusan.

\subsection{Pemecahan Masalah}

Untuk pemecahan masalah yang sudah penulis uraikan maka diperlukan dashboard pada Widuri yang khususnya digunakan untuk mendapatkan informasi mengenai data laporan penulisan pada Widuri. Media yang akan digunakan yaitu 
menggunakan Google Spreadsheet, data yang didapatkan dari data laporan penulisan dimasukkan kedalam Google Spreadsheet.

1. Data yang dikumpulkan yaitu dari Google Form yang sebelumnya sudah dijalankan dalam Website Widuri.

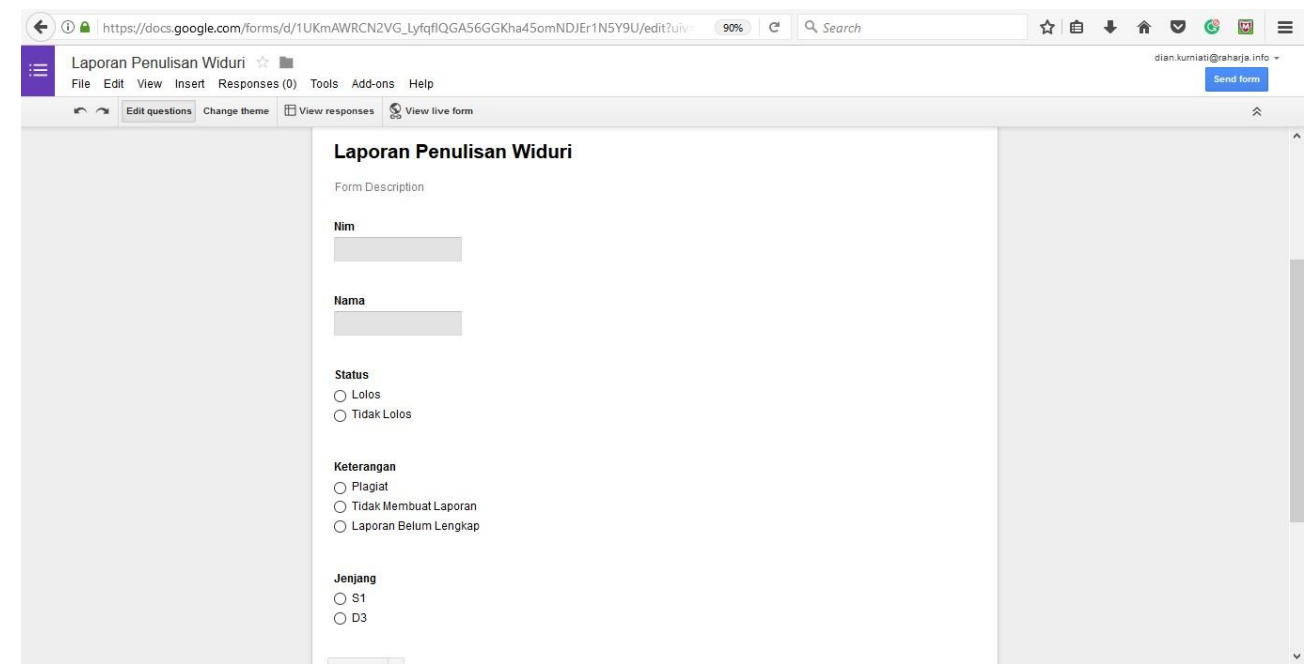

Gambar 3. Prototype Google Form Data Laporan Penulisan

Google Form atau yang bisa disebut dengan Rinfo Form adalah ekstensi khusus dari Google Sheets. Dengan Form, pengguna dapat membuat dokumen formulir untuk dipublikasikan ke web. Google Form merupakan salah satu tools yang terdapat dalam google drive yang bisa diakses secara free. Pada tampilan diatas merupakan tampilan form penginputan data secara online yang di embed kedalam Website Widuri.

2. Data yang diambil yaitu dari Google Form yang dikumpulkan didalam Google Spreadsheet.

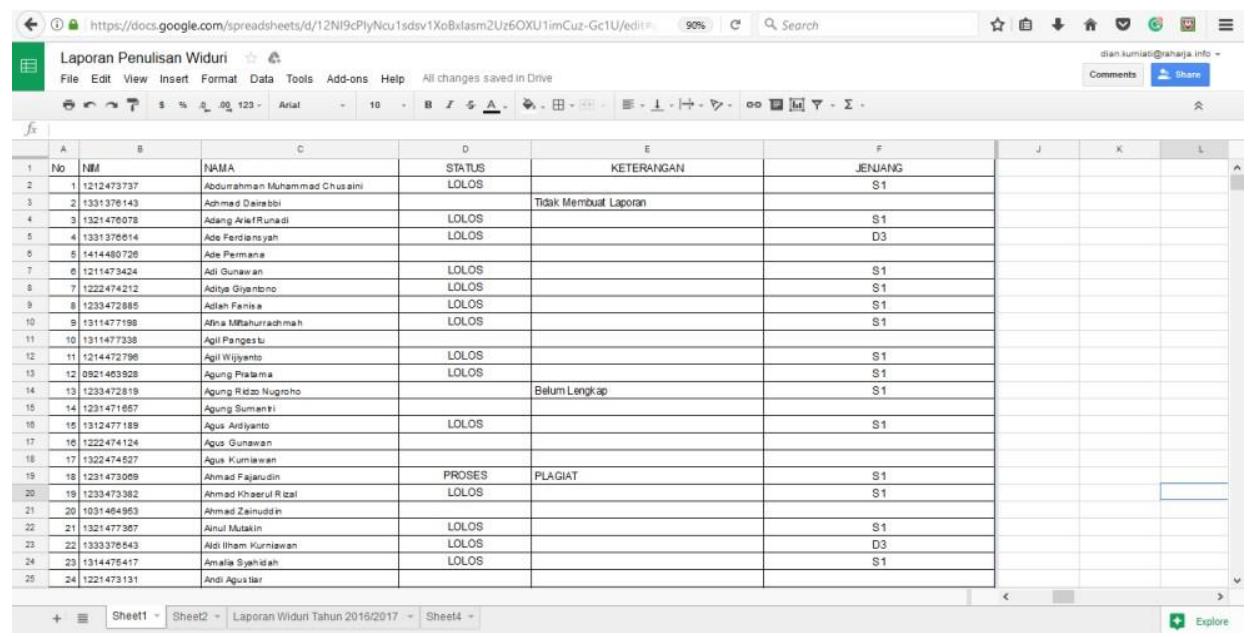

Gambar 4. Prototype data laporan penulisan 
Gambar diatas merupakan prototype data yang terkumpul dari Google Form dan data tersebut yang akan diolah untuk ditampilkan pada dashboard Widuri.

3. Untuk membuat Dashboard, Widuri menggunakan Google Spreadsheet yang sebelumnya untuk data keseluruhan harus di sortir terlebih dahulu menggunakan formula seperti COUNTIF.

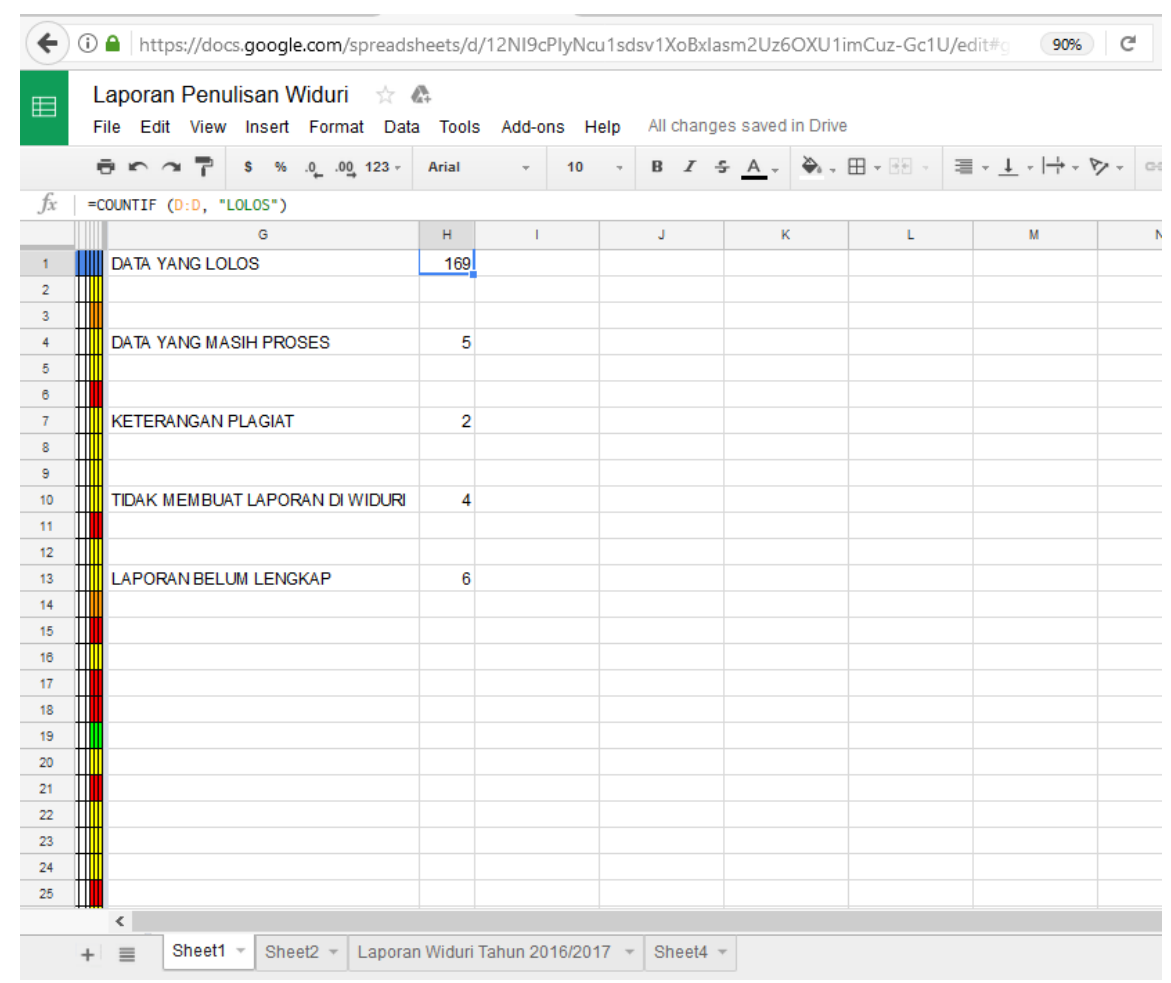

Gambar 5. Prototype data sortir Laporan Penulisan Widuri

Gambar diatas merupakan prototype data sortir yang diambil menggunakan formula Google Spreadsheet untuk membuat tampilan pada dashboard dan chart.

4. Setelah di sortir kemudian membuat grafik dengan cara blok data yang telah di sortir sesuai dengan data yang telah dikelompokkan, insert chart lalu pilih chart dan terakhir setting chart agar terlihat jelas saat membaca chart tersebut. 


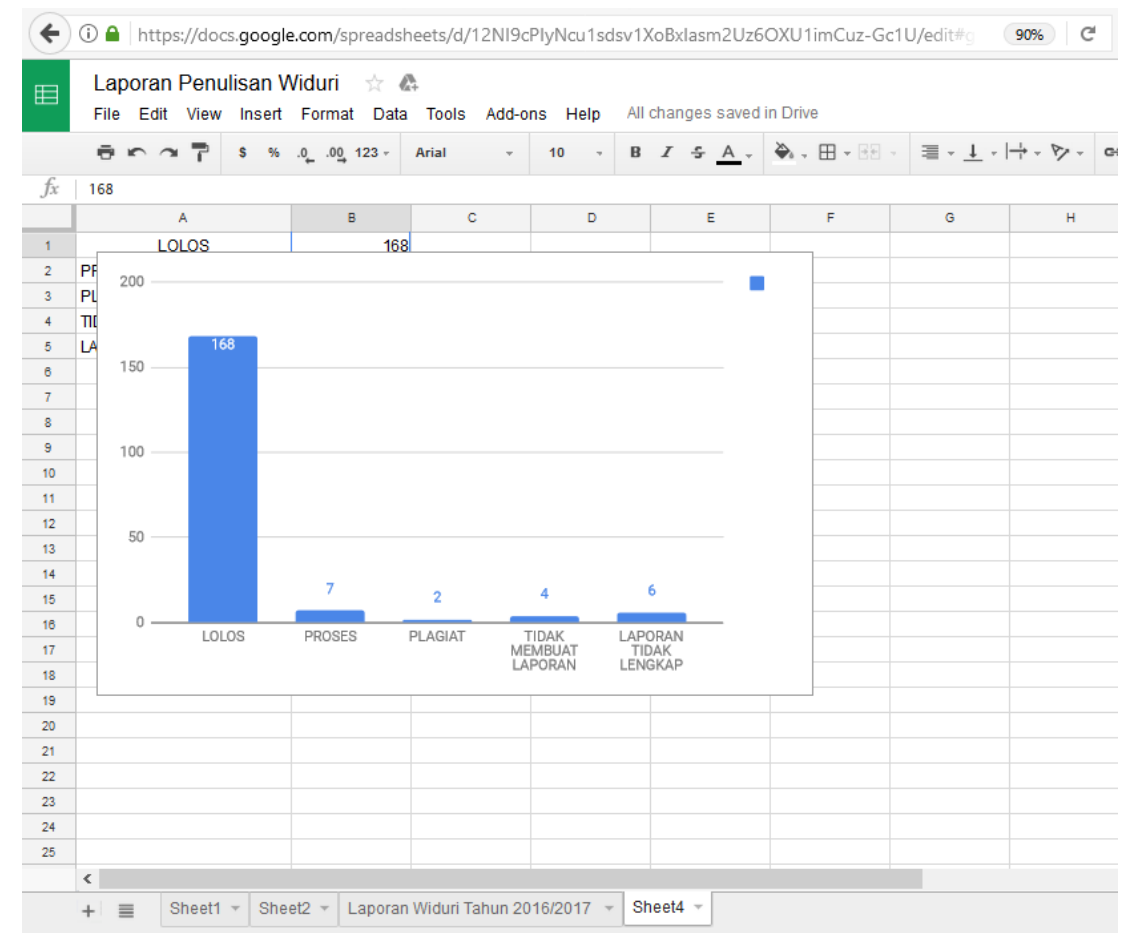

Gambar 6. Prototype Grafik Data Laporan Penulisan

Gambar diatas merupakan gambar grafik yang dibuat menggunakan tools yang disediakan oleh Google Spreadsheet. Dari gambar diatas merupakan chart yang digunakan untuk Dashboard Widuri yang menggunakan diagram batang.

5. Pengambilan data untuk membuat dashboard yaitu dengan menggunakan beberapaGoogle Sheet yang berbeda akan tetapi masih dalam satu Spreadsheet yang sama. 


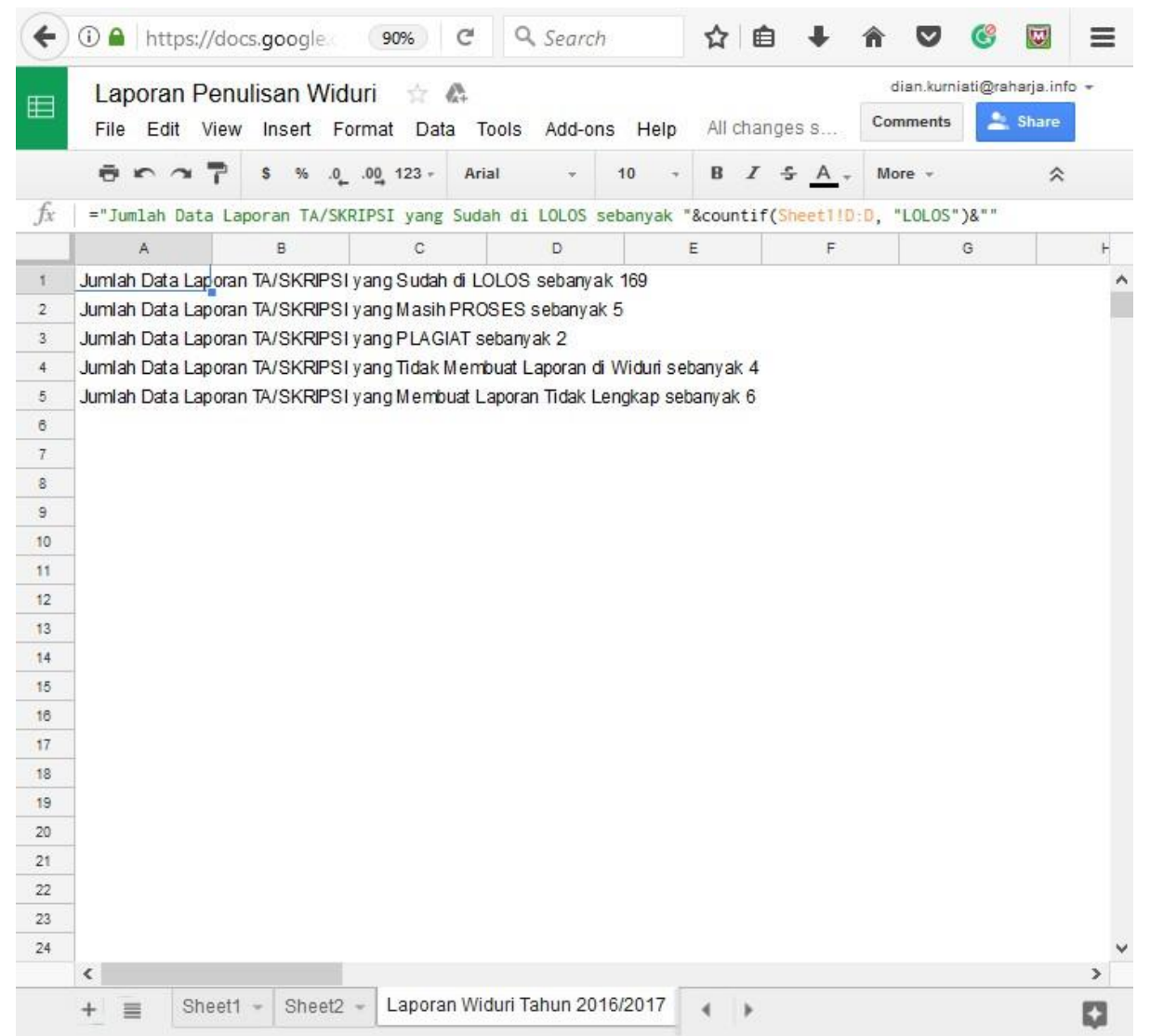

Gambar 7. Prototype tampilan Dashboard

Gambar diatas merupakan Prototype tampilan dashboard yang sudah dibuat dengan cara memakan beberapa cell seperti gambar diatas. Berikut ini merupakan salah satu formula untuk memanggil data dari Google Spreadsheet.

\subsection{Implementasi}

Informasi yang sudah dijadikan satu pada Google Sheet lalu akan di embed kedalam Website Widuri (widuri.ilearning.me)

1. Buka Website Widuri pada page yang telah dibuat yaitu dashboard. 


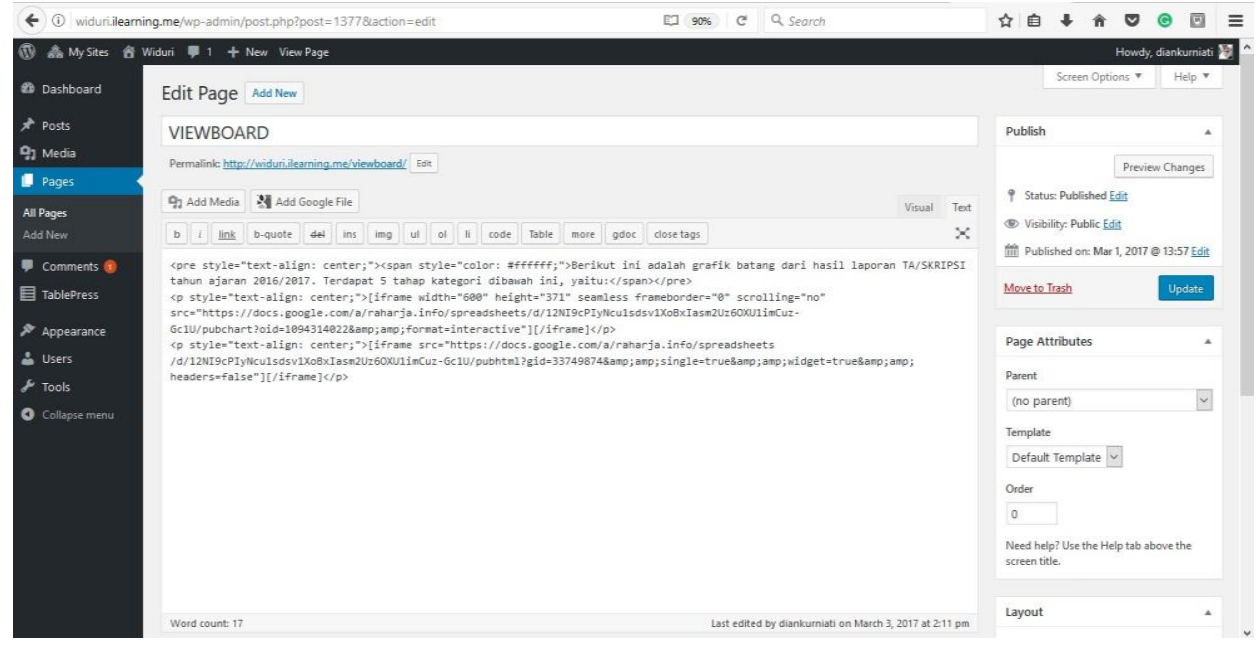

Gambar 8. Page Widuri

Gambar diatas merupakan salah satu page yang ada didalam Website Widuri yaitu perihal page viewboard (dashboard) yang digunakan untuk mengedit tampilan page tersebut.

2. Buka Google Spreadsheet kemudian pilih data Sheet yang telah dibuat setelah itu klik publish to the web dan copy link.

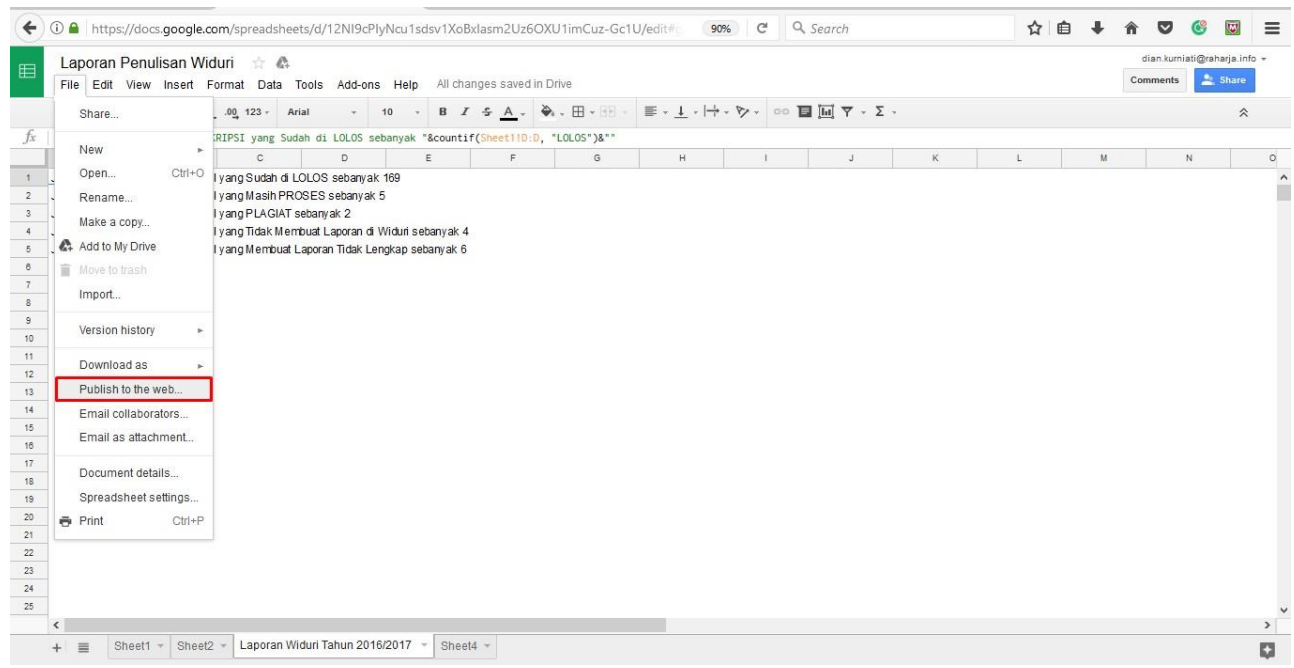

Gambar 9. Pengambilan link pada Google Sheet

Gambar diatas merupakan pengambilan link pada Google Sheet tertentu untuk di embed kedalam Website Widuri.

3. Pada tampilan page viewboard, paste link tersebut kedalam codingan embed dibawah ini:

[iframe src='https://docs.google.com/a/raharja.info/spreadsheets/d/e/2PACX- 
1vQyJsqqkPnVgDkKkQI0ROapIW s7AbvOvS2d21R-M745D1F5NkHyrLGicoyD83vFEu_M_afn8YZhFYU/pubhtml?gid=33749874\&amp;single=true \&amp; id get=tr ue\&amp;headers=false"][/iframe]

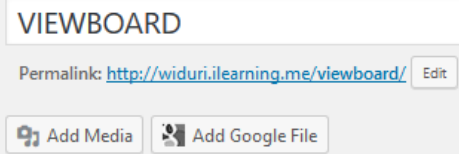

\section{Gambar 10. Script embed}

Gambar diatas merupakan codingan embed idari Google Spreadsheet agar dapat ditampilkan pada dashboard Widuri yang menampilkan informasi keseluruhan data laporan penulisan yang ada pada Widuri.

4. Agar dapat menampilkan hasil dari Script embed diatas maka tahap terakhir di publish dan dibawah ini adalah tampilan akhir dari data keseluruhan laporan penulisan yang ada pada Widuri.

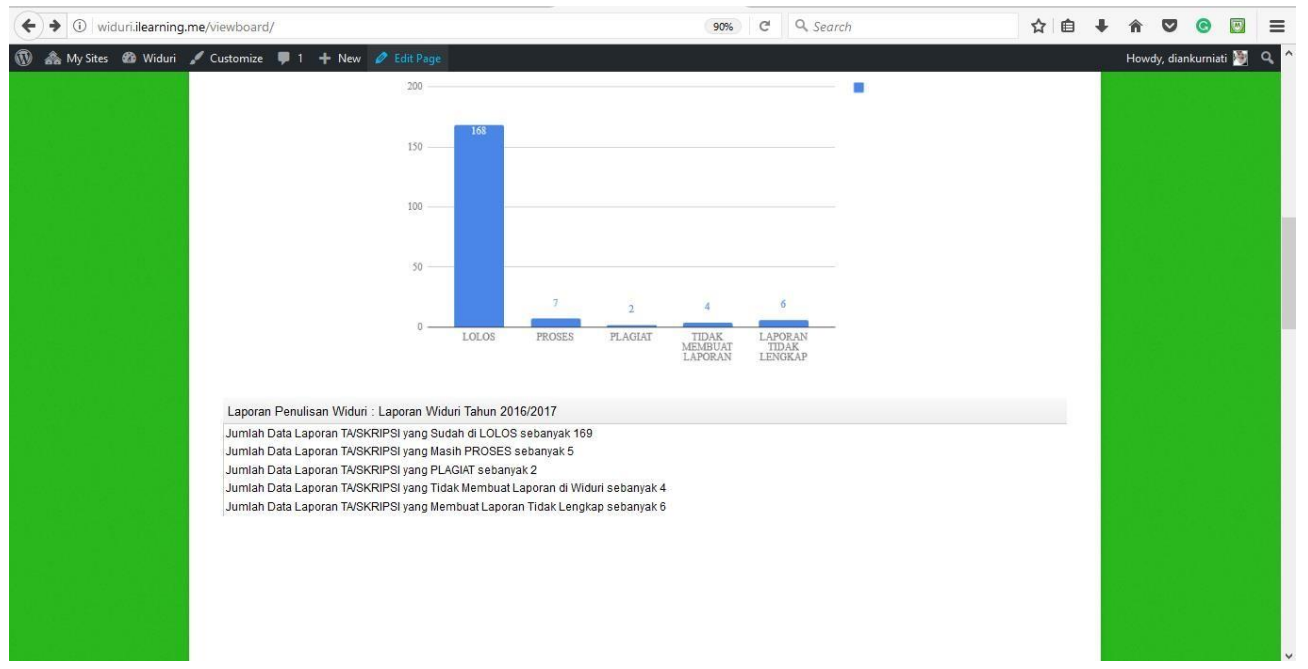

Gambar 11. Tampilan dashboard Data Laporan Penulisan Widuri

Gambar diatas merupakan tampiloan dashboard yang telah selesai di embed dan telah dipublikasikan dalam website Widuri. Terdapat informasi yang berguna untuk Tim Widuri dalam mengambil suatu keputusan secara tepat dan akurat. Angka yang 
ada pada tampilan dashboard akan mengalami perubahan sesuai dengan data yang diinput melalui Google Form yang sudah disediakan di Website Widuri.

\section{KESIMPULAN}

Dapat disimpulkan bahwa pemanfaatan Google Spreadsheet pada dashboard Widuri telah sesuai dengan kebutuhan yang ingin ditampilkan. Maka dapat disimpulkan dengan adanya Dashboard Widuri ini dapat :

1. Dashboard Widuri dapat memberikan data secara real time.

2. Dashboard Widuri dapat mempermudah untuk pengambilan keputusan.

3. Dashboard Widuri dapat memberikan informasi yang lebih akurat dan lebih mudah mengetahui jumlah laporan penulisan yang ada pada Widuri.

\section{SARAN}

Berdasarkan keseluruhan yang telah penulis uraikan maka dengan ini penulis dapat menyimpulkan ssaran yaitu sebagai berikut ini :

1. disarankan agar Dashboard Widuri tidak hanya menampilkan informasi mengenai laporan penulisan Widuri melainkan informasi mengenai kinerja para operator atau Widuri Wayang sebagai tim Widuri.

2. Perlunya tampilan pengembangan Dashboard Widuri agar lebih menarik.

\section{DAFTAR PUSTAKA}

[1] Januarita, Dwi, and Teduh Dirgahayu. "Pengembangan Dashboard Information System (DIS)." Jurnal Infotel 7.2 (2015): 165-169.

[2] Partners, Technology. Complete Organization In One Mobile Dashboard (2014).

[3] Scipioni, Antonio, et al. "The Dashboard of Sustainability to measure the local urban sustainable development: The case study of Padua Municipality." Ecological indicators 9.2 (2009): 364-380.

[4] McCullough, Bruce D., and A. Talha Yalta. "Spreadsheets in the cloud- not ready yet." Journal of Statistical Software 52.7 (2013): 1-14.

[5] Rasdiana, Erlita, and Nursam Somantri. "Penerapan RinfoSheet Sebagai Media Penunjang Pembuatan Laporan Untuk Mahasiswa." Technomedia Journal 1.1 (2016): 36-49.

[6] Warsito, Ary Budi, Muhamad Yusup, and Erlita Rasdiana. "Pemanfaatan RinfoDocs Sebagai Media Penyusunan Draft Laporan Dalam Proses Bimbingan Tugas Akhir Pada Perguruan Tinggi." Jurnal CCIT 8 (2015).

[7] Handayani, Indri, Herrafika Kusumahati, and Alpiah Nurul Badriah. "Pemanfaatan Google Spreadsheet Sebagai Media Pembuatan Dashboard pada Official Site iFacility di Perguruan Tinggi." SISFOTENIKA 7.2 (2017): 177-186. 